\title{
Goiás in the geopolitical architecture of the Portuguese America
}

\author{
Fernando Lobo Lemes[1]
}

\begin{abstract}
The strategy adopted by the king of Portugal from the decade of $1740 \mathrm{on}$, with the fragmentation of the ecclesiastical jurisdiction of Rio de Janeiro and the implementation of the captaincies of Goiás and Mato Grosso, gives a new orientation to Lisbon diplomacy in relation to Portuguese America. In this context, we seek to understand the new statute of the mines of Goiás in the negotiations aiming to guarantee and to enhance the colonial administration control over the territories situated by the frontier with the Spanish empire.
\end{abstract}

Keywords: Goiás; geopolitics; frontier.

\section{Goiás na arquitetura geopolítica da América portuguesa}

\section{Resumo}

A estratégia adotada pelo rei de Portugal a partir dos anos 1740, com a fragmentação da jurisdição eclesiástica do Rio de Janeiro e a instalação das Capitanias de Goiás e Mato Grosso, imprime uma nova orientação na diplomacia de Lisboa com relação à América portuguesa. Nesse contexto, buscamos compreender o novo estatuto das minas de Goiás nas negociações que visam garantir e ampliar o controle da administração colonial sobre os territórios situados na fronteira com o império espanhol. Palavras-chave: Goiás; geopolítica; fronteira.

\section{Goiás en la arquitectura geopolítica de la América portuguesa}

\section{Resumen}

La estrategia adoptada por el rey de Portugal desde los años 1740, con la fragmentación de la jurisdicción eclesiástica de Río de Janeiro y la instalación de las Capitanías de Goiás y Mato Grosso, imprime una nueva orientación en la diplomacia de Lisboa referente a la América portuguesa. Por lo tanto, se buscó comprehender el nuevo estatuto de las minas de Goiás en las negociaciones, con el objetivo de asegurar y ampliar el control de la administración colonial sobre los territorios situados en la frontera con lo imperio español.

Palabras-clave: Goiás; geopolítica; frontera.

\section{Goiás dans l'architecture géopolitique de l'Amérique portugaise}

\section{Resumé}

La stratégie adoptée par le roi du Portugal dans les années 1740, avecla fragmentation de la juridiction ecclésiastique du Rio de Janeiro et l’installationdes Capitaineries du Goiás et Mato Grosso, imprime une nouvelle orientation dans la diplomatie de Lisbonne. Dans ce contexte, nous cherchons à comprendre le nouveau statut des mines du Goiás dans les négociations qui envisagent garantir les territoires dans la frontière avec l'empire espagnol.

Mots-clés: Goiás; géopolitique; frontière. 
o provide incentives to create villages and cities and to implement administrative, jurisdictional and religious structures, the King of Portugal tried to consolidate his strategic presence in the West frontier of Portuguese America. In this aspect, the second half of the $18^{\text {th }}$ century witnessed the occupation of the region as a way of establishing the bases of the Portuguese dominion facing the opposition of the Spanish dominion. ${ }^{1}$

The strategies adopted by the Portuguese diplomacy presented a new direction towards the Lisbon project for the region of the mines of Goiás, in two different senses. Firstly, the Prelate of Goiás was created, confirmed by the Bull of Pope Benedict XIV, in 1746 that was connected to the Bishopric of Mariana, fragmenting the ecclesiastic jurisdiction of Rio de Janeiro. Secondly, the division of the Captaincy of São Paulo led to the creation of the following captaincies: Goiás and Mato Grosso. Together, these actions would give Vila Boa created in July, 1739, being the only village in the region of the mines of Goiás during the entire $18^{\text {th }}$ century - a new dimension among some negotiations that aimed to ensure and enlarge the limits of the west frontier of Portuguese America. In this scenario, both initiatives promoted the resizing of the mines of Goiás in its regional context, thus replacing the actions and role played by Vila Boa de Goiás as an important political and economic space in the frontier region based on the new geopolitical Empire.

\section{The creation of the Prelate of Vila Boa de Goiás}

The creation of the Prelate of Vila Boa de Goiás was in accordance with a calendar that was closely associated with the negotiations established between Lisbon and Rome. After consulting with the Governor of the Captaincy of São Paulo, in 1719, members of the Overseas Council in Lisbon were concerned about the need to create new Bishoprics that could work inside Portuguese America.

Understanding the spiritual and religious needs of the believers who lived in an extensive region under the responsibility of the Bishopric of Rio de Janeiro, the initiative was especially aimed at enhancing the presence of the Crown and the Church in the new conquered territories, thus discouraging the movement of the Spanish and thwarting, at the same time, the high rates of smuggling of gold produced in the territories dedicated to mining. ${ }^{2}$

The territory under the jurisdiction of the Diocese of Rio de Janeiro was very large in size - which consisted of the Captaincy of São Paulo, and the regions of Minas Gerais, Goiás and Mato Grosso, besides the South of Portuguese America. Hence, there were several correspondences exchanged between the members of the Overseas Council and the Portuguese King, which reveal that the Crown was aware of the existing difficulties caused by the expansion of this

'About the definitions of frontiers in Portuguese America, see Maria Fernanda Batista Bicalho, "Sertão de Estrelas. A Delimitação das Latitudes e das Fronteiras na América Portuguesa”, Varia Historia, vol. 21, Belo Horizonte, 1999, p. 73-85.

${ }^{2}$ Cristina de Cássia Pereira Moraes, "Deus e o Diabo no sertão dos Guayazes: abusos e desmandos do vigário da Vara de Vila Boa", Sociedade e Cultura, vol. 9, n. 1, Goiânia, 2006, p. 91. 
Bishopric. This situation certainly stimulated the interest of the King to promote its division, ${ }^{3}$ which was effectively proposed from 1745 on. The King of Portugal, John VI, personally intervened with the Holy See and requested the creation of the Bishoprics of São Paulo and Ribeirão do Carmo, as well as the Prelates of Goiás and Cuiabá. ${ }^{4}$

With such initiatives, the Portuguese King proposed the creation of a new map to Rome, including therein the ecclesiastic jurisdiction in America, which would reorganize the geography of the Bishopric of Rio de Janeiro. The latter would be limited to the South by river Paraíba, which would become the initial mark of the future bishopric of São Paulo, and such jurisdiction would reach the South of Portuguese America. To the West, the jurisdiction of Rio de Janeiro would maintain its reach up to the border with the new Bishopric of Vila de Ribeirão do Carmo. It would include the territory of the Captaincy of Minas Gerais (except for the regions of São Francisco and Paracatu, which would meet under the jurisdiction of the Bishoprics of Pernambuco and Bahia, respectively). The Bishopric of São Paulo would be limited to the North by the Archbishopric of Bahia and to the West, by the Prelate of Goiás. ${ }^{5}$

Despite the Crown's intervention with the Papacy to deal specifically with the division of the Diocese of Rio de Janeiro, the Roman Curia did not immediately contemplate to protect the interests of Lisbon. Rome argued about the impossibility to create a Papal Bull that would create Bishoprics in America and Asia simultaneously:

Since this is a general grant for all of the current bishoprics, and for the ones to be created in America and Asia, it is not possible to insert two creations in the same bull and such a broad and unlimited grant is not possible. ${ }^{6}$

However, another factor brought in a new type of difficulty for the result of a decision from Rome that could favor the Portuguese Empire: the mobilization of the Spanish Crown. Troubled by the aggressive diplomacy performed by the Portuguese king and by the inconsistent definition of geographic boundaries between both empires in South America - which clearly involved the region of the mines of Goiás and Cuiabá —, the Spanish Crown

\footnotetext{
${ }^{3} \mathrm{AHU} / \mathrm{GO} /$ Attached to the document of the general internal affairs of Goiás, Francisco de Atouguia Betencourt e Lira, to the secretary of State of the Marine and Overseas, Francisco Xavier de Mendonça Furtado, referring to the records of information on the facts against the former governor and general captain of Goiás, Antônio da Cunha Sotomaior; Vila Boa de Goiás, May $29^{\text {th }}, 1760$ [Cx. 17, D. 988]. Biblioteca da Ajuda, Códice 1173, cota 49 - VTTT-41. See also Cristina de Cássia Pereira Moraes, op cit., p. 93.

${ }^{4} \mathrm{AHU} / \mathrm{GO} / \mathrm{Consultation}$ of the Oversease Council to the king John V concerning the creation of the bishoprics of São Paulo and Ribeirão do Carmo, in the district of the bishopric of Rio de Janeiro, as well as the prelates of Goiás and Cuiabá in the same district; about the contributions owed to the prebendary bishops and chaplains; the means that point to the expenses; the buildings of the cathedrals and places in which they should be established; Lisboa, April 10 th 1745 [CX. 3, D. 264].

${ }^{5}$ Cristina de Cássia Pereira Moraes, "Deus e o Diabo no sertão dos Guayazes: abusos e desmandos do vigário da Vara de Vila Boa", Sociedade e Cultura, vol. 9, n. 1, Goiânia, 2006, p. 94.

'Biblioteca da Ajuda, Códice 1173, cota 49 - VTTT-4, cited in Cristina de Cássia Pereira Moraes, "Deus e o Diabo no sertão dos Guayazes: abusos e desmandos do vigário da Vara de Vila Boa”, Sociedade e Cultura, vol. 9, n. 1, Goiânia, 2006, p. 93.
} 
disagreed with the concession of a new ecclesiastic jurisdiction of the region of the mines of Goiás and Cuiabá that would favor Portugal's intentions. He feared a threat to his hegemony in the frontier that was enshrined in the Treaty of Tordesillas. ${ }^{7}$

The authority of the Holy See to create Bishoprics was based on Canonical Law, which was associated with the definition of borders for their probable jurisdictions. Knowing this, the King of Portugal worked to ensure the dominion over a territory in which the Spanish Crown was interested. The King of Portugal had the privileges resulting from the patronage and regal authority based on religion. So he turned into some sort of Apostolic Vicar who represented the interests of the Church, both in his Kingdom and in conquered territories. Hence, he thought it was up to Rome to ratify the choices made by him on spiritual terms. ${ }^{8}$

Since the Portuguese King was determined on the creation of new Bishoprics and Prelates in America, Pope Benedict XIV promulgated the Bull Candor Lucis Aeternae, thus creating the dioceses of São Paulo and Mariana, as well as the Prelates of Goiás and Cuiabá. ${ }^{9}$ Counting on the possibilities provided by the royal patronage and also on a deliberate strategy to consolidate the occupation of the territories located beyond the meridian defined by the Treaty of Tordesillas, the King of Portugal obtained the blessings and

\footnotetext{
${ }^{7}$ Single reference concerning the territorial division between Portugal and Spain in America, the Treaty of Tordesillas was signed on June 7, 1494, and divided the world into two hemispheres, by a meridian located 370 leagues away from Cape Verde, leaving to Spain everything to the West, and to Portugal everything to the East. The treaty established the deadline of ten months so that the line dividing the possessions of both kingdoms could be established. However, the line would never be effectively fixated. Its location on maps was an exercise of conceptual projection that did not consider the physical or geographical aspects, nor the occupation of the territory. About the subject, see Iris Kantor, "Diplomatic uses of Brazil's island myth cartographic and historiographic polemics", Varia historia, vol. 23, n. 37, 2007, p. 70-80. See also Luis Adão da Fonseca, O tratado de Tordesilhas e a diplomacia luso-castelhana no século XVI, Lisboa, Edições Enapa, 1991. ${ }^{8}$ The patronage right of the king, established in $16^{\text {th }}$ century by John III, involved the bishoprics of the lands conquered by Portugal and created by the monarch, both in the kingdom and overseas. The Holy See pointed out the people and provided the bishoprics, even though it accepted proposals from the Crown in order not to cause conflicts. Kings like Afonso III, Manuel, Philip I, John IV and Peter II constantly tried to earn the patronage right and to infiltrate in the Holy See. In 1740, Pope Benedict XIV decided to give the king of Portugal the right to the benefits of the new bishoprics, however, being restricted to the nomination of bishops, canons and other dignities of the old bishoprics. This regime of royal patronage, in practice, was maintained until the Law of Separation, in 1911, after the establishment of the Republic, in 1910. Based on this conception, the king of Portugal conquered the privilege of indicating the apostolic delegate in Portugal, besides proposing names to the vacant bishoprics all over the kingdom, and received from Benedict XIV, in December, 1748, the title of most loyal king. Cf. Cristina de Cássia Pereira Moraes, "Deus e o Diabo no sertão dos Guayazes: abusos e desmandos do vigário da Vara de Vila Boa", Sociedade e Cultura, vol. 9, n. 1, Goiânia, 2006, p. 94. About the patronage in the Portuguese empire, see Charles R. Boxer, Portuguese society in the tropics. The municipal councils of Goa, Macao, Bahia and Luanda. 1510-1800, Madison and Milwaukee, The University of Wisconsin Press, 1967 and Idem, A Igreja e a Expansão Ibérica, 1440-1770, Lisboa, Edições 70, 1990. About the Portuguese patronage in the east, see Antônio da Silva Rego, O Padroado Português do Oriente e a sua historiografia, 1838-1950, Lisboa, Academia Portuguesa de História, 1978. Idem, Le Patronage portugais de l' Orient, Lisboa, Agência Geral do Ultramar, 1957 e Teotônio R. de Souza, "O Padroado português do Oriente visto da Índia. Instrumentalização política da religião", Revista Lusófona de Ciência das Religiões, n. 13/14, 2008, p. 413-430

'Luiz Antônio da Silva e Souza, "Memória sobre o descobrimento, governo, população e cousas mais notáveis da Capitania de Goyaz (1812)", In: José Mendonça Teles, Vida e obra de Silva e Souza, Goiânia, UFG, 1998, p. 107.
} 
the recognition of Rome with respect to its expansion towards the West in violation of the Treaty. ${ }^{10}$

After the creation of the Bishoprics of São Paulo and Mariana in 1745, the Prelates of Goiás and Mato Grosso were effectively established in 1749. Coincidently, it was in the same year that the division of the Captaincy of São Paulo took place due to the creation of the Captaincies of Goiás and Cuiabá.

\section{The creation of the Captaincies of Goiás and Mato Grosso}

The idea to create an autonomous Captaincy in Goiás, apart from that in São Paulo, came up in the 1730s. This was an alternative to the early implementation of the control mechanisms defined by Lisbon. Therefore, in 1735, even before the royal provision that determined the establishment of the first village in the mines of Goiás, the Governor Antônio Luís de Távora, Count of Sarzedas, was concerned about the persistent conflicts that existed in the region. He was aware of the need for an alternative to the weak presence and the regulating power of the Crown. Therefore he convened an extraordinary meeting in the city of São Paulo to comment on the two projects: the creation of a Captaincy and the establishment of a village in Sant'Anna or Meia Ponte. When the Royal Commissioner, Martinho de Mendonça ${ }^{11}$, arrived in Brazil at the instance of the King of Portugal with the objective of analyzing this matter, the second project prevailed. ${ }^{12}$

Later, in 1736, the Monarch allowed that the Governor of São Paulo, Antônio Luiz de Távora, the Count of Sarzedas, could create a village in the mines of Goiás, but he insisted on a report on the need to establish a separate Government from the Captaincy of São Paulo:

I let you, Count of Sarzedas, Governor and General Captain of the Captaincy of São Paulo, know that I have made the decision to pass the mines of Goyas for you to establish a location and found a Village I must order you, based on a resolution of the seventh of this month and year, after consulting with my overseas council, to inform us of exactly all of the needs in these districts, and they should be formed in the so called Goyas as a separate government, or more Villages and justices so I can decide whatever seems to be more convenient. ${ }^{13}$

\footnotetext{
${ }^{10}$ As stated by Jaime Cortesão, "Portugal obtained from the Pope the recognition and a transcending sanction to its expantion to the West, and, as a consequence, its violations to the Treaty of Tordesillas". This act "reverted in favor of Portugal, and not Spain, and implicated an anticipation under religious uti possidetis". Cf. Jaime Cortesão, Alexandre de Gusmão e o Tratado de Madri, Rio de Janeiro, Instituto Rio Branco, 1952, p. 175. "About the trajectory of the Royal Commissioner Martinho de Mendonça de Pina e de Proença, sent by the king of Portugal in the mid 1730s, to assist the governos of the South of Portuguese America, see Irenilda Reinalda B. R. M Cavalcante, O comissário real Martinho de Mendonça: práticas administrativas na primeira metade do século XVIII, Tese de Doutorado em História, UFF, Rio de Janeiro, 2010.

12José Martins Pereira de Alencastre, Anais da Província de Goiás (1863), Goiânia, Governo de Goiás, 1979, p. 56. ${ }^{13} \mathrm{AHU} / \mathrm{GO} /$ Letter to the governor and general captain of São Paulo, Luís de Mascarenhas, to the king John V, in response to the provision of February 11, 1736, about the great distance between São Paulo and the mines of Goiás and the need of the latter to have its own government; Vila Boa de Goiás, Septembter $30^{\text {th }}, 1739$ [CX. 1, D. 68].
} 
However, the response to the King was not sent by Sarzedas, who died in Goiás in August, 1737, but by his successor, Luiz de Mascarenhas. ${ }^{14}$ Since he was in the mines right after having developed the ritual to establish Vila Boa and the Senate Chamber, he wrote to the king and expressed his point of view on the matter. It seemed both like a justification for him to stay in Goiás and a convincing argument so that an autonomous Captaincy could be formed. He emphasized the long distance between the mines and the city of São Paulo, besides the difficulties to build a land route instead of the existing river routes to the mines of Cuiabá. He also cited the attention that the Royal Treasury deserved and the collection of quinto (tax charged by the Portuguese Crown over the gold found in its Colonies), and then defended the presence of a Government in the mines:

[...] because by his orders any diligence of the Royal Service is executed better and faster [...]. And by the aforementioned arguments, it seems to me that the Governor should provide help to these mines, and not São Paulo, because in this city his assistance is not and cannot be useful. ${ }^{15}$

Later, in March, 1737, the General Superintendent of the mines of Goiás, Gregório da Silva, also suggested the necessity of creating a new Captaincy to the Monarch. He expected the possibility of a broad jurisdiction that could include the mines of Cuiabá. ${ }^{16}$

The Captaincies of Goiás and Mato Grosso had
connections with respect to the political and
administrative architecture, which demonstrated
the intentions of Lisbon for this complicated frontier
region of America

However, the effective separation of the Captaincy of São Paulo and the establishment of the Captaincy of the mines of Goiás did not take place immediately. Even though it was always a real possibility in the evaluations of the Crown, in 1739, the authorities of Lisbon chose to found Vila Boa de Goiás (the King's order was from 1736) instead of adopting the immediate creation of an autonomous captaincy, due to the strategic importance for

\footnotetext{
${ }^{14}$ Antônio Luís de Távora was the governor of the captaincy of São Paulo from August 15, 1732, until his death, in the village of Trairas, in the mines of Goiás, on August 29, 1737.

${ }^{15} \mathrm{AHU} / \mathrm{GO}$, op cit.

${ }^{16} \mathrm{AHU} / \mathrm{GO} /$ Letter from the general superintendant of the mines of Goiás, Gregório Dias da Silva, to the king John $V$ about the order against the residentes of the mines of Tocantins, who asked for better rates due to the decrease of their papers and responding to the provision which ordered them to inform about all of the ecessities, and to form separate governments or more villages and justices. Vila Boa de Goiás, March 19 ${ }^{\text {th }}$, 1737 [CX. 1, D. 31].
} 
the villages to be inside the colonial space. ${ }^{17}$ Therefore, the King of Portugal only announced the creation of the Captaincies of Goiás and Mato Grosso in 1748. He informed the Governor Luiz de Mascarenhas about the separation of the Captaincy of São Paulo:

Since Your Majesty considered the existing need to separate the general Captaincy [...] for its broad extension did not allow the necessary initiatives to be taken in time due to the long distances that it comprehends, and since the governor resides very far away, it was chosen to create two governments and general captaincies, being the first one in Mato Grosso, which includes all of the county of Cuiabá until Rio Grande, and the second one in Goiás $[\ldots]^{18}$

Therefore, the procedures to establish the new Captaincy and to define the respective positions were rapidly developed. On July 26, 1748, the King named Marcos de Noronha, former Governor of the Captaincy of Pernambuco, to be the Governor. ${ }^{19}$ He published a submission form in Lisbon to select those who were interested in being the Secretary of the Government of

\footnotetext{
${ }^{17} \mathrm{About}$ the strategic role and function played by the villages and cities in the colonial world, and, more specifically, in Portuguese America, there is extensive bibliography available. Among others: Renata Malcher de Araújo, "A Razão na selva: Pombal e a reforma urbana da Amazônia", Camões. Revista de Letras e Culturas Lusófonas, n. 15-16, 2003, p. 151-165; Idem, A urbanização do Mato Grosso no século XVIII. Discurso e método. Tese de Doutorado em História da Arte, Universidade Nova de Lisboa, Lisboa, 2000; Maria Fernanda Batista Bicalho, A cidade e o Império: o Rio de Janeiro no século XVIII, Rio de Janeiro, Civilização Brasileira, 2003; Idem, "O Rio de Janeiro no século XVIII: A transferência da capital e a construção do território centrosul da América portuguesa”, Centro Interdisciplinar de Estudo da Cidade/Unicamp (on-line). Available from: <http://www.ffch.unicamp.br/ciec/revista/artigos/dossie1.pdf>. Accessed on: 15 June 2009; Nasr Fayad Chaul; Luís Sérgio Duarte (orgs.), As cidades dos sonhos: Desenvolvimento urbano em Goiás, Goiânia, UFG, 2004; Laurent Vidal (org.), La Ville au Brésil (XVIIle-XXe). Naissances, renaissances, Paris, Les Indes Savants, 2008; Cláudia Damasceno Fonseca, Des terres aux villles de l'or. Pouvoir et territoires urbains au Minas Gerais (Brésil, XVIIle siècle), Paris, Centre Culturel Calouste Gulbenkian, 2003; Rita Costa Gomes, "A Reconquista e o imaginário da cidade peninsular", In: Yvette Kace Centero; Lima de Freitas, Simbólica do espaço: Cidades, Ilhas, Jardins, Lisboa, Estampa, 1991, p. 43-57; Nauk Maria de Jesus, "A Câmara da Vila Real do Senhor Bom Jesus do Cuiabá: um breve panorama (1727-1800)", Fronteiras, vol. 10, n. 17, Dourados, 2008, p. 163-175; Idem, Na trama dos conflitos. A administração na fronteira oeste da América portuguesa (1719-1778), Tese de Doutorado em História, UFF, Rio de Janeiro, 2006; Mary Karasch, "The periphery of the periphery? Vila Boa de Goiás, 1780-1835”, In: Christine Daniels; Michael V. Kennedy, Negotiated Empires. Centers and Peripheries in the Americas, 1500-1820, New York, Routledge, 2002, p. 143-169; Magnus Roberto Pereira de Mello, A forma e o podre: duas agendas da cidade de origem portuguesa nas idades medieval e moderna, Tese de Doutorado em História, UFPR, Curitiba, 1998; Fernando Lobo Lemes, "Pouvoir colonial et réseau urbain: Vila Boa de Goiás au XVIIIle siècle", In: Martine Acera; Guy Martinière; Guy Saupin; Laurent Vidal (orgs.), Les Villes et le monde. Du Moyen Âge au XXe siècle, Rennes, Presses Universitaires de Rennes, 2011, p. 107-127; Catarina Madeira Santos, Goa é a Chave de Toda a India. Perfil Político da Capital do Estado da India (15051570), Lisboa, CNCDP, 1999; Laurent Vidal, "Os trilhos da história do Brasil urbano", Ler História, n. 48, 2005, p. 75-85; Idem, "Capitais sonhadas, capitais abandonadas. Considerações sobre a mobilidade das capitais nas Américas (séculos XVIII - XX)", História, vol. 30, n. 1, 2011, p. 3-36; Idem, Mazagão: la ville que traversa I'Atlantique - Du Maroc à I'Amazonie (1769-1783), Paris, Flammarion, 2005; e, Idem, "Sous le masque du colonial - Naissances et "décadence" d’une Vila dans le Brésil moderne: Vila Boa de Goiás au XVIIIe siècle," Annales HSS, n. 3, 2007, p. 577-606.

${ }^{18} \mathrm{AHG}$ [Arquivo Histórico de Goiás]/DA [Documentos Avulsos], Carta do Secretário de Estado a Luiz de Mascarenhas, governador de São Paulo, comunicando a divisão da Capitania; Goiás, 17 de maio de 1748. ${ }^{19} \mathrm{AHG}$ [Arquivo Histórico de Goiás]/DA [Documentos Avulsos], Decreto do rei D. João V nomeando o [conde dos Arcos], Marcos de Noronha, governador e capitão-general de Goiás; Lisboa, 26 de julho de 1748 [Cx. 5, D. 374].
} 
the Captaincy of Goiás. ${ }^{20}$ In January, 1749, the Monarch determined the immediate transfer of Marcos de Noronha and asked him to take over the Government of Goiás. ${ }^{21}$ After arriving in Vila Boa, he met with the locals and the officials of the Senate Chamber who were expecting him to effectively discharge the powers ensured for the position of Governor in the new Captaincy of Goiás. The newly-named Secretary of the Government, Ângelo Santos Cardoso, had described the celebration of this meeting in the official record of the ceremony:

On the eightieth of November, 1749, in this Vila Boa of Goiás, in their chamber, at the presence of the Senate Chamber from the same village and its people, the royal document is read, in which Your Majesty names the governor and general-captain of these mines, the most eminent and most excellent Mr. D. Marcos de Noronha, and he took over the same government. I prepared this term, which was signed by the most eminent and most excellent Mr. governor and general-captain and chamber officials. And I, Ângelo dos Santos Cardoso, secretary of government, wrote and signed it. D. Marcos de Noronha. Ângelo dos Santos Cardoso. Agostinho Luiz Ribeiro. Manoel da Silva. Inácio Barbosa da Silva. João Ferreira Barros. ${ }^{22}$

Since they were created simultaneously, the Captaincies of Goiás and Mato Grosso had many similarities. They also had connections with respect to the political and administrative architecture, which demonstrated the materialization of the project: the intentions of Lisbon for this complicated frontier region of America.

\footnotetext{
20/dem, Requirement of Clemente Carlos de Azevedo Cotrim, to the king John V, asking to be considered for the position of secretary of the government in the captaincy of Goiás; Lisbon, August 5, 1748 [Cx. 5, D. 376]; Idem, Consultation of the Overseas Council to the king John V, about naming the people for the position of secretary of the government of Goiás; Lisbon, August 8, 1748 [Cx. 5, D. 378]. Actually, it seems to be an auction for the position of secretary of the government of the mines of Goiás, which would be taken by the one who paid more for the job. According to António Manuel Hespanha, a royal provision from 1740 increased the regime of donation to all of the overseas documents. Since then, fulfilling the documents was performed by auction, and then they were sold to those who could pay more. This transaction did not correspond to a real sale, since the paid amount consisted of a mere donation connected to the duty of gratitude towards the monarch who conceived this position. Even if the auction system elevated the fiscal income, the sale of these official positions ended up favoring rival groups which, due to the competitive disputes, offered more significant donations, with possible damage to the public interest and the people with more merit and less money. Cf. António Manuel Hespanha, "A constituição do Império português. Revisão de alguns enviesamentos correntes", In: João Fragoso; Maria Fernanda Bicalho; Maria de Fátima Gouvêa (orgs.), O Antigo Regime nos Trópicos: a dinâmica imperial portuguesa (séculos XVI-XVIII), Rio de Janeiro, Civilização Brasileira, 2001, p. 184-185.

${ }^{21}$ Governor of the captaincy of Pernambuco and, later, vice-king of Brazil, the indication of Marcos de Noronha for the position of governor of Goiás follows a common tendency since the $17^{\text {th }}$ century in the Portuguese Empire. Most of the Brazilian territory was ruled by members of the "first nobility". According to Nuno Gonçalo monteiro, it is the case of Bahia, for instance, even after the transfer of the capital to Rio de Janeiro; of Goiás, from 1749 on; Grão-Pará, Mato Grosso, Minas Gerais, Pernambuco, Rio de Janeiro (until 1763) and São Paulo (after 1721). The more inside the $18^{\text {th }}$ century, Brazil had a tendency to become the only possible colonial destination for successors of the main noble houses of the kingdom. Cf. Nuno Gonçalo Monteiro, "Trajetórias sociais e governo das conquistas: notas preliminares sobre os vice-reis e governadores-gerais do Brasil e da India nos séculos XVII e XVIII", In: João Fragoso; Maria Fernanda Bicalho; Maria de Fátima Gouvêa (orgs.), O Antigo Regime nos Trópicos: a dinâmica imperial portuguesa (séculos XVI-XVIII), Rio de Janeiro, Civilização Brasileira, 2001, p. 281.

22José Martins Pereira de Alencastre, Anais da Província de Goiás (1863), Goiânia, Governo de Goiás, 1979, p. 88.
} 
Located in the central area of the South-American Continent and in the frontier with the Spanish domain, Mato Grosso had mining as its main economic activity. It was exactly facing the Provinces of Moxos and Chiquitos. Hence the formation of the Captaincy of Mato Grosso reveals the intention of the Portuguese Crown to accomplish its territorial conquest in the region. This was also intended to stop the progress of the Spanish Jesuit missions that were being established at the right bank of river Guaporé. ${ }^{23}$

The creation of both Captaincies in a single act demonstrates the relevance of the Portuguese King's decision (Map 1). An interesting analysis by Nauk Maria de Jesus points out the importance of the mining regions of Goiás and Mato Grosso in the context of the Portuguese Empire. It indicates the strategic importance of the space which culminated in the cohesion and the Portuguese conquests in America.

More than that, the article seeks to explain the region as a connecting point between the North and the South, through the Platine and Amazon basins, where the meridian dividing the Portuguese and Spanish dominions is located, and also a space of separation between two empires (Portugal and Spain) and two States (Brazil and Grão-Pará). ${ }^{24}$

Indeed, there is no doubt as to the intentions and actions triggered by Portugal in this delicate frontier zone. The eyes of the King of Portugal were turned especially to the region of Mato Grosso: if the creation of Vila Boa de Goiás was elaborated and put into practice only during the 1730s, Vila Real do Senhor Bom Jesus do Cuiabá came a decade earlier in relation to the wishes of the Crown for the region, mainly due to its privileged position at the West side, inside Spanish territory, in theory.

In July, 1726, Rodrigo César de Menezes, former Governor of São Paulo, went along the river route Tietê-cuiabá. He traveled from the port of Araritaguaba towards the village of Sant'Anna and discovered the first gold fields in that region. His goal was to found the first village in the mines of Cuiabá. In January, 1727, after repeating the same ritual adopted by the Portuguese Empire to build villages, he marked the locations of public buildings and built pelourinho (whipping post) with the participation of local residents. He chose the ordinary Judges and City Councilors, and established the Senate Chamber in Vila Real do Senhor Bom Jesus de Cuiabá. Unlike Goiás, whose only village was Vila Boa during the $18^{\text {th }}$ century, the Captaincy of Mato Grosso would soon have a new Capital. In 1752, the village Bela da Santíssima Trindade was founded to be the Government Headquarters and became the place where the Governor, the military troops, the trustee, the offices of the internal affairs and the Gold Foundry were located. In each one of the villages, there was a Senate Chamber.

\footnotetext{
${ }^{23}$ Nauk Maria de Jesus, "A câmara da Vila Real do Senhor Bom Jesus do Cuiabá: um breve panorama (17271800)", Fronteiras, vol. 10, n. 17, Dourados, 2008, p. 164.

${ }^{24}$ The importance of the captaincies of Goiás and Mato Grosso has been minimized by historiography with time, as properly mentioned by Nauk Maria de Jesus. According to her, in the "history of colonial Brazil the mining área is, by excellence, Minas Gerais, and the most conflicted border is the South, and in this contexto the west and the north borders were also minimized". Cf. Nauk Maria de Jesus, "A câmara da Vila Real do Senhor Bom Jesus do Cuiabá: um breve panorama (1727-1800)", Fronteiras, vol. 10, n. 17, Dourados, 2008, p. 164.
} 


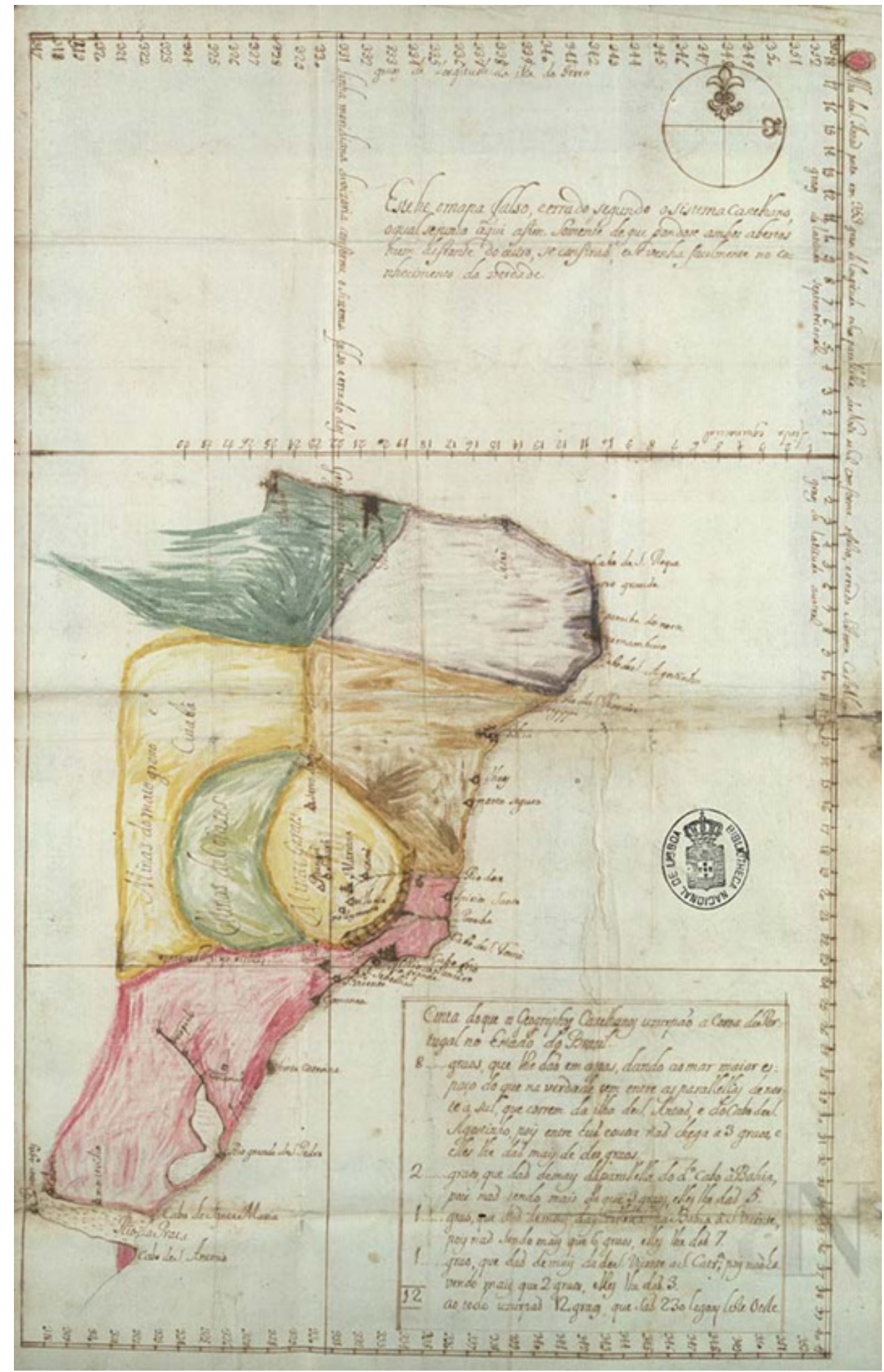

Map 1. Political situation of Portuguese America: Captaincies of Goiás (center) and Mato Grosso (left)a.

aFrancisco de Seixas, fl. ca. 1767. In: Noticias dos Titulos do Estado do Brazil e de seos limites austraes eseptemtrionaes no temporal/Francisco de Seixas. - [1767]. - Entre f. [13] e 1. Pertence à Livraria de Alcobaça. Mapa político/Brasil, ca. 1767. CDU: 918.1(084.3). 912"17"(084.3). COD. 1408. A cartografia do Brasil nas Coleções da Biblioteca Nacional (17001822), Biblioteca Nacional, Lisboa. 
Afterwards, the Forts of Coimbra and Príncipe da Beira were created. Also, the villages of Albuquerque, Maria and Casalvasco were founded. The political strategy of the Portuguese is evident from all of these actions. With the creation of villages and the establishment of Forts, the Portuguese wanted to seize total power over this region, blocking it to the Spanish people.

Though both Empires made major efforts and great investments in this frontier region, it can be seen that Portugal owned the largest possible territorial extension by preserving the occupied spaces and their natural riches. Through a geographically inverted bias, the King of Portugal justified his occupation in the combat-front facing the Spanish. The boundaries guaranteed consolidation and offered a new format to Portuguese America, which helped in the maintenance of such a frontier. Considering the opposite direction in relation to the historical movement of the occupation of America, the Crown conquests took up from the last frontier defined by the Captaincy of Mato Grosso to the frontiers of the coast, surrounded by the beaches of the Atlantic Ocean. This is what the Governor of the Captaincy of Mato Grosso, Luiz de Albuquerque de Mello Pereira e Cáceres, meant when he wrote to the Governor of Goiás describing the importance of the place commanded by him. The role of Mato Grosso consisted especially on the defense of the "[...] last domains of Your Majesty, which on this side cover all of the others in America".25

\section{The route to Goiás: Oxygen for the region of Mato Grosso}

From our point of view, the grandiosity that this border represents for the monarch regulated the importance of the mines and, later on, of the Captaincy of Goiás inside the colonial project conducted by Lisbon. At first, the mines of Goiás were like oxygen for the region of Mato Grosso, because they provided support to the mines of Cuiabá. The mines of Goiás provided a land route to the City of São Paulo, an alternative to the river route, which was the only existing connection with the city of São Paulo. The route of monsoons, as were called the river navigations towards the West of America, was composed of rivers that connected São Paulo to Cuiabá. This river route was perilous and difficult, and the journey lasted about five to six months. This difficult river path was replaced by the land route between Vila Boa de Goiás and Vila Real do Senhor Bom Jesus do Cuiabá. ${ }^{26}$

\footnotetext{
${ }^{25} \mathrm{AHU} / \mathrm{GO} /$ Attachment of the document of the governor and the general captain of Goiás, baron of Mossâmedes, José de Almeida Vasconcelos de Soveral e Carvalho, to the secretary of State of the Marine and overseas, Martinho de Melo e Castro, sending a certificate of all of the gold shipping to assist the captainship of Mato Grosso. Vila Boa de Goiás, June 22, 1774 [Cx. 27, D. 1779].

${ }^{26}$ Monsoons were specific river expeditions from the $18^{\text {th }}$ century, leaving from the port of Araritaguaba, current Porto Feliz, in the Valley of Médio Tietê, and demanding the gold mines of Cuiabá, in Mato Grosso. They went through about 3,500 kilometers on several rivers, amongst rapids, leaps and indigenous attacks to provide food, manufactured products and transportation of men and gold. Due to the set of peculiarities, specific techniques of the tide and fabrication of canoes, as well as the collection of tragic occurrences, the monsoons gained major development with time, almost absurd, almost legendar. Its disappearance was due to the opening of land routes to Goiás and the appearance of the mule troops. Cf. Valderez Antônio da Silva, Os fantasmas do rio: um estudo sobre a memória das monções do Vale do Médio Tiete, Dissertação de Mestrado em História Cultural, Unicamp, Campinas, 2004.
} 
The sum of several factors led to the creation of this alternative land route. Certainly, the expansion and the increase in gold production resulted in the pressure of migration of people towards Goiás and Mato Grosso. The commercial interests that were at stake also encouraged the need to create a connection route between these two regions that belonged to the same economic and social scenario, "the Mining Complex". ${ }^{27}$

Besides, before the separation of the Captaincy of São Paulo and the creation of the Captaincies of Goiás and Mato Grosso, there was insecurity in relation to the local geopolitical scenario as the region was surrounded by the presence of the Spanish people, across the border and along the boundaries of the river route. The actions of territorial integration in the region became feasible by the creation of a land route to the mines of Goiás. The frequent news and rumors of conflicts between the two Empires forced local authorities to realize that the land connection with the village of Sant'Anna and later, with Vila Boa, was an efficient means of communication and transport. It provided an escape route, eased transportation of supplies, and military support whenever required. The concern of the officials of the Senate Chamber of Cuiabá for such a route was demonstrated in April, 1736:

\begin{abstract}
[...] in the past few canoes that came from the town there was news for great preparation, not only in the kingdom, but all over America for the war that for moments was expected to be declared with the Crown of Castela and for this land to be invaded by the Castilians in short notice, with no place for help to arrive from, besides the journey from the river, which can be blocked by the enemies for these reasons and many others $[. . .]^{28}$
\end{abstract}

The officials of the Chamber also found that, in addition to the risks of the river journey and the possibility of war against the Castilians, the insecurity of the monsoons was directly related with the collection of the Royal Treasury.

[...] it is understood that there is a safe way for the collection of the Royal Farm, as declared by the order of Your Majesty, and the river journey is not safe, because besides the major risks of waterfalls and pagans that have invested our troops as nearly happened in the present, the dangers of the Castilians due to the wars may easily destroy our troops, and for the safety of the gold shipping of the Royal Treasury, common good of the people and the conservation of this land Your Majesty has recommended all of human diligence to open the aforementioned path [to Goiás]. ${ }^{29}$

Coincidently, the same problem was a matter of concern for the Governor of São Paulo, Luiz de Assis Mascarenhas, which was revealed in a letter to John $\mathrm{V}$ three years later. He wrote his opinion about the pernicious consequences of navigation for the development of the region of Mato Grosso as also his preference and the value attributed to the terrestrial route between Cuiabá and Goiás.

\footnotetext{
${ }^{27}$ Alcir Lenharo, Crise e mudança na frente oeste de colonização, Ensaios 1, Cuiabá, UFMT/PROEDI, 1982, p. 17-19. ${ }^{28}$ Auto e Termo da Junta do Senado da Câmara da Vila Real do Senhor Bom Jesus do Cuiabá, de 18 de abril de 1736, UFMT/NDHIR, Microficha n. 14, D. 176.

${ }^{29}$ Auto e Termo da Junta do Senado da Câmara da Vila Real do Senhor Bom Jesus do Cuiabá, de 18 de abril de 1736, UFMT/NDHIR, Microficha n. 14, D. 176.
} 
According to him,

A great part of this captaincy are the mines of Cuyabá, and due to the difficulties in navigation they are not so populated as they would be if there were terrestrial routes, and since this village (Vila Boa) currently has an open road through which more people have crossed safely in relation to their lives and farms in comparison to the navigation route, and in a shorter period of time it is demonstrated that it is frequently used by the people, providing more safety for royal quintos, and in the following year these will be able to come through there $[\ldots]^{30}$

Therefore, in the end of 1739, Assis Mascarenhas informed the Monarch that, from 1740 onwards, the Royal quinto collected from the mines of Cuiabá could be directed to the Foundry House of São Paulo by the land route that would pass by Vila Boa de Goiás so as to ensure faster journey in a safer and secure way. Inside the mining group, the micro frontiers were integrated little by little, leading to the consolidation of Portuguese America: the route from Bahia to Minas Gerais and Goiás was complemented and extended to the mines of Cuiabá.

\section{The frontier between two Empires: The gold of Goiás transferred to Mato Grosso}

In the geography of gold, if the communication by land with the mines of Goiás represented important progress for the maintenance of the west boundary of America, the creation of Vila Boa and, afterwards, the establishment of the Captaincies of Mato Grosso and Goiás intensified this connection. The responsibility of financing the activities proposed by Lisbon fell on the mines of Goiás and ensured the possession and control over the region by the Portuguese.

After Marcos de Noronha was named the first Governor of Goiás, the communication with the mines of Cuiabá and the transfer of important sums of gold to the captaincy of Mato Grosso were among the first orders of the Monarch, given in January, 1749. In response to the King of Portugal's query on the new route to Cuiabá, the Governor stated as follows:

[...] this communication is in advance [...] because travelers and dwellers know that with a journey of twenty five days they can transport their load from one government to another, and this is very useful, I hope it is the most efficient way for them to be persuaded by the various instances, and I will do everything I can so that they continue through this path. ${ }^{31}$

According to the instructions of Lisbon, the cost support should be addressed by the Governor of Mato Grosso. Marcos de Noronha, the Governor of Mato

\footnotetext{
${ }^{30} \mathrm{AHU} / \mathrm{GO} /$ Letter of the governor and general captain of São Paulo, Luís de Mascarenhas, to king John V, in response to the provision of February 11th 1736 , about the great distance between São Paulo and the mines of Goiás and the need for the later to have its own government; Vila Boa de Goiás, September 30, 1739 [Cx. 1, D. 68]. ${ }^{31} \mathrm{AHU} / \mathrm{GO} /$ Letter to the governor and general captain of Goiás, Count of Arcos, Marcos de Noronha, to the king John V, in response to the provision about the improved communication between Goiás and Cuiabá and about the cost support conceived to Mato Grosso; Vila Boa de Goiás, December 18, 1749 [Cx. 5, D. 42O].
} 
Grosso offered to help, but stated that it would not be possible for him to send the financial resources requested by the King immediately. However, not long after that the Crown determined the establishment of an annual contribution in gold, produced from the mines of Goiás. This measure was aimed to support the military troops and to pay for the employees who worked to delimit the geographical boundaries with the Spanish America. ${ }^{32}$

Actually, if the intention of Lisbon was to promote the spatial integration of the mining group in America, the role to provide the actions triggered in Mato Grosso would belong to the captaincy of Goiás from 1751 on. Since then, the gold of Goiás ensured the logistical and financial support that was essential to promote the integrity of the frontier. It helped in maintaining military activities, delimiting geographical boundaries of the territory occupied by the Portuguese and the construction of Forts. Several of such initiatives were aimed at achieving control over the conquered regions by the Portuguese King against the intentions of the Spanish Crown.

\section{The peculiarities of the frontier region, as well as the insecurity and fear of the Spanish attacks, favored the Captaincy of Mato Grosso}

With such objective, from 1757 on, the King of Portugal reaffirmed the obligation of the annual shipping to the Captaincy of Mato Grosso, even though he did not prescribe the exact amount that should be transferred. So, to confirm the importance given to the investments and transfers of resources that financed the movements in the frontier, he authorized the shipping. The gold paid by the trustee of the Royal Treasury or by the treasury of Quintos, collected in the Captaincy of Goiás could be used to finance the movements. This arrangement resulted in emptying the gold available in the trustee's safe. The trustee wrote:

[...] the gold needed for the so called shipping, I will send it, even as a result of the product of my royal quintos; because for me nothing is more important than providing the means for the subsistence of the troops, and, for the administration of justice in such a remote conquest, where distance makes the regularity of the Government more precise. ${ }^{33}$

\footnotetext{
${ }^{32}$ Cristina de Cássia Pereira Moraes, "Deus e o Diabo no sertão dos Guayazes: abusos e desmandos do vigário da Vara de Vila Boa", Sociedade e Cultura, vol. 9, n. 1, Goiânia, 2006, p. 91-92.

${ }^{33} \mathrm{AHU} / \mathrm{GO} / \mathrm{Attachment}$ of the document of the governor and the general captain of Goiás, Luís da Cunha Menezes, to the secretary of State of the Marine and overseas, Martinho de Melo e Castro, about the shipping that annually assists the captaincy of Mato Grosso, with the map and the list of all the shipping leaving from Goiás to the aforementioned captaincy; Vila Boa de Goiás, July 9, 1779 [Cx. 31, D. 1979].
} 
However, from 1775 on, an order from the King of Portugal fixed the annual contribution from the safe of the Captaincy of Goiás as 8 (eight) arrobas of gold. ${ }^{34}$ The argument put forth by the Governor of Mato Grosso, Luiz de Albuquerque de Mello to Pereira and Cáceres on the transfers and investments carried out by the Captaincy of Goiás were registered in a letter written from Vila Bela in October, 1776. This letter was addressed to the Governor of Goiás in an attempt to sensitize him to the problems faced by the Government of the mines of Cuiabá. The letter elaborated why major expenses could not be avoided as there was a need: "by the well-established fear that our neighbors might want to try some sudden onslaught in this expanded frontier, as they do in the South Provinces". Also it explained therein why States have to move the military troops with the objective of occupying the "dangerous places" in the boundaries of the Provinces of Chiquitos and Moxos, whose activity might be highly expensive. Besides, due to this suspicion concerning the Spanish overtures, he was obliged to provide ammunition, personnel and food for the detachment of Nova Coimbra, 200 leagues to the South of Cuiabá. ${ }^{35}$

There were further justifications mentioned by the Governor in his letter. The gold transferred from the Captaincy of Goiás was used to finance the construction of Fort Príncipe da Beira, 170 leagues away from Vila Bela and for the activities developed in the new village of Vila Maria. Essentially, the amount was used to attract the indigenous people coming from the Spanish missions of Chiquitos, "which Your Majesty demands to attract at all costs", to form military troops to defend the Portuguese territory. Therefore, according to the Governor of Mato Grosso, the application of the gold from Goiás promoted "the two very important purposes of improving the State and at the same time destroying the neighbor on that region, which can lead to great damage in times of war". ${ }^{36}$

Also, according to Governors Pereira and Cáceres, besides all of these expenses, there were more costs with the "extraordinary military roll", and "politics, which cannot be harmed". It was also because of the necessity to fulfill the payment to the creditors, so that the "progress of commerce" was not damaged. Also, there should be no lack of "first need items" in "Royal warehouses", nor for the works in "agriculture and mining", in order to avoid all kinds of "public damage".37

Indeed, the gold produced in the mines of Goiás was very important for the Portuguese actions in the frontier since Spanish domain was close to the Captaincy of Mato Grosso since 1757. Therefore, Goiás was playing its role as the leading actor in the Colonial Project of the mining regions, by financially supporting the frontier and providing the logistical support for the Portuguese domains in America.

${ }^{36} \mathrm{AHU} / \mathrm{GO} / \mathrm{Attachment}$ of the document of the governor and the general captain of Goiás, Luís da Cunha Menezes, to the secretary of State of the Marine and overseas, Martinho de Melo e Castro, about the shipping that annually assists the captaincy of Mato Grosso, with the map and the list of all the shipping leaving from Goiás to the aforementioned captaincy; Vila Boa de Goiás, July 9, 1779 [Cx. 31, D. 1979].

${ }^{37}$ Idem, Ibidem.
} 
However, the high investments that were demanded for meeting the above investments became a burden for the economy of Goiás. In 1776, the former Governor, José de Almeida Vasconcelos de Soveral e Carvalho, explained the difficulties for the Captaincy of Goiás to continue to transfer the large sums as required by the Monarch to the commercial registry of the Royal Treasury.

He stated that he had helped the Captaincy of Mato Grosso since 1772, when he became the Governor of Goiás, with the sum of eight arrobas of gold annually. In 1777, the Governor of Mato Grosso requested a higher value: ten arrobas. Soveral e Carvalho was unhappy and pointed out that this value corresponded to almost all of the revenue from the quintos collected that year. Apparently irritated with the higher sum requested, he took the opportunity to make a statement:

And with the duty to reason with this registry that such income has specific applications, so it cannot be completely used for Mato Grosso, and that before, on the contrary and by the orders of Your Majesty each of the captaincies should save their income so that they can cover their own expenses without helping each other [...] It will be established not to exceed the usual shipping to Mato Grosso, so that such captaincy can look for effective means to use this same shipping moderately, and for that, in this occasion, we recommend the same to the Governor and the General Captain of the aforementioned captaincy. ${ }^{38}$

After Soveral e Carvalho, his successor, Luiz da Cunha Menezes, continued to send the pre-established eight arrobas as the annual shipping to the Governor of Mato Grosso. He described the difficulties of the Captaincy and stated that the act of sending more gold might be detrimental to the economy in Goiás:

I determine, in this same year, to send the pre-established eight arrobas of gold, if it is possible, or the amount I can afford, because in a frontier captaincy, it is not suitable that amounts of forces are known, not even concerning our own payments. ${ }^{39}$

However, Mato Grosso faced the problems of the peculiarities of the frontier region, as well as the insecurity and fear of the Spanish attacks. In those "last domains of Your Majesty", the privileges seemed to be considerable but necessary: a fiscal stimulus conceived by the Queen Maria I to the miners of Mato Grosso (in force until 1779) known as half-quinto gold grant, stimulated the collection of the Royal tax. Such concession, however, could reduce the income of mines of Cuiabá, but it also resulted in emptying the already broken safes of the Captaincy of Goiás. Mato Grosso, however, justified its claims for larger amounts of gold from Goiás.

${ }^{38} \mathrm{AHU} / \mathrm{GO} / \mathrm{Attachment}$ of the document of the governor and the general captain of Goiás, Luís da Cunha Menezes, to the secretary of State of the Marine and overseas, Martinho de Melo e Castro, about the shipping that annually assists the captaincy of Mato Grosso, with the map and the list of all the shipping leaving from Goiás to the aforementioned captaincy; Vila Boa de Goiás, July 9, 1779 [Cx. 31, D. 1979].

$39 /$ dem, Ibidem. 
In 1778, the governor Pereira e Cáceres had optimistic expectations for the economy of the mines of Mato Grosso. Such expectations were created by the end of the grant of the quinto (temporary privilege conceived by the Crown, which consisted of a reduction in the tax charged by the gold extracted in the captaincy) from 1780 on. After warning the governors of Goiás in 1779 about the extreme poverty in his captaincy, he stated that the shipping of eight arrobas of gold was essential for that year. However, he tried to relieve the damage caused in the finances of the neighboring captaincy. Trying to soften the negative effects of his request, he said he was flattered

[...] that for the following [year] of 1780 , such a great amount will not be needed because most of the debts will be paid, and the increased income we expect from the Foundry House from this capital [Vila Bela], because the privilege or grant of the quinto gold, provided to these peoples by the same Madam [Maria I] will have finished. ${ }^{40}$

Finally, after 22 years of annually transferring eight arrobas of gold on an average to the Governors of Mato Grosso, ${ }^{41}$ facing numerous complaints of the Governors of the Captaincy of Goiás and with the end of the half-quinto grant on July 8, 1779, Queen Maria I determined that the values of the annual shipping should be altered, reducing and limiting it to 300 gold marks a year.

In spite of that, the agreement established since the creation of both Captaincies did not end, in which the Governors of Goiás paid for the maintenance of the activities carried out in the frontier of both Empires, in the heart of South America. However, gold transfers did not suffer any continuity problem. In the year of 1780, an inflexion point was reached and a relief for the finances of the Captaincy of Goiás occurred.

\section{Cartography, Treaties and Territory: Goiás in the frontier of two Empires}

The creation of the Prelates and Captaincies of Goiás and Mato Grosso should be observed as a group of actions which was a larger project envisaged by Lisbon. Since the beginning, the trajectory of the actions of the King in the region coincided with the delimitation of territories between the possessions of Portugal and Spain, which only took place with the agreements reached

\footnotetext{
${ }^{40} \mathrm{AHU} / \mathrm{GO} / \mathrm{Attachment}$ of the document of the governor and the general captain of Goiás, Luís da Cunha Menezes, to the secretary of State of the Marine and overseas, Martinho de Melo e Castro, about the shipping that annually assists the captaincy of Mato Grosso, with the map and the list of all the shipping leaving from Goiás to the aforementioned captaincy; Vila Boa de Goiás, July 9, 1779 [Cx. 31, D. 1979].

${ }^{41} \mathrm{AHU} / \mathrm{GO} /$ Attachment of the document of the governor and the general captain of Goiás, Luís da Cunha Menezes, to the secretary of State of the Marine and overseas, Martinho de Melo e Castro, about the shipping that annually assists the captaincy of Mato Grosso, with the map and the list of all the shipping leaving from Goiás to the aforementioned captaincy; Vila Boa de Goiás, July 9, 1779 [Cx. 31, D. 1979]. It seems to be clear that such shipping and financial support for the captaincy of Mato Grosso took place since the foundation of both captaincies, in 1749. However, officially, the contribution begins to be regular as a result of the royal provision of July $7,1757$.
} 
through the Treaty of Madrid, on January 13, $1750 .{ }^{42}$ However, the guidelines that defined and shaped its full execution could not be identified before 1749 .

The founding of Vila Real do Senhor Bom Jesus do Cuiabá and, later on, the creation of Vila Boa de Goiás, indicated that the Crown was specifically conscious about the advances into the Western frontier of America, which were in disobedience with the clauses established by the Treaty of Tordesillas. ${ }^{43}$ However, if Portugal trespassed the limits of the Western side of the globe, Spain was doing the same on the Eastern side. ${ }^{44}$ Therefore, the geostrategic position of Vila Boa de Goiás was placed beyond the boundaries established by the Treaty of Tordesillas. This is sufficient for us to realize how much Vila Real do Senhor Bom Jesus do Cuiabá was advanced into the territory belonging to the Spanish Crown (Map 2).

We know that despite its old age and frequent violations, at least theoretically the guidelines of the Treaty of Tordesillas remained in force and valid for the two Kingdoms up to 1750, when the Treaty of Madrid came into force. For all of this long period, a series of factors made it difficult to point out the exact location of the line dividing the possessions of the Iberian Kingdoms on the globe: the uncertainty about the initial 370 league boundary, the doubts concerning the real dimension of the league, longitude and even the real dimensions of

\footnotetext{
42The Treaty of Madrid was established between king John V, of Portugal, and king Fernando VI, of Spain, on January 13, 1750, with the objective of defining the boundaries between the respective South-American colonies, thus putting an end to the constant disputes. The objective of the Treaty of Madrid was to replace the Treaty of Tordesillas, which was no longer respected in practice. Negotiations were based on the Map of Courts, favoring the use of rivers and mountains to delimit geographical boundaries. The document celebrated the Roman principle of private right, uti possidetis, ita possideatis (who owns for a fact should own as a right), defining the approximate lines of Brazil today. About this matter and its consequences, see, specially, Jaime Cortesão, Alexandre de Gusmão e o Tratado de Madrid, Lisboa, Livros Horizonte, 1984.

${ }^{43}$ About the cartography in the $17^{\text {th }}$ century in Goiás and Mato Grosso, see Leonora de Castro Barbo; Andrey Rosenthal Schlee, "As estradas coloniais na Cartografia Setecentista da Capitania de Goiás", Anais do I Simpósio Brasileiro de Cartografia Histórica, Paraty, 2011, p. 1-20; Antônio César Caldas Pinheiro; Gustavo Neiva Coelho (orgs.), O diário de viagem do Barão de Mossâmedes: 1771-1773, Goiânia, Trilhas Urbanas, 2006; Antônio Teixeira Neto, "Cartografia, território e poder: dimensão técnica e política na utilização de mapas", Boletim Goiano de Geografia, vol. 26, n. 2, 2006, p. 49-69; André Ferrand Almeida, "Entre a Guerra e a Diplomacia: os conflitos luso-espanhóis e a cartografia da América do Sul (1702-1807)", In: João Carlos Garcia (coord.), A Nova Lusitânia: imagens cartográficas do Brasil nas coleções da Biblioteca Nacional (1700-1822), Lisboa, Comissão Nacional para as Comemorações dos Descobrimentos Portugueses, 2001; Mario Clemente Ferreira, "Cartografar o sertão: a representação de Mato Grosso no século XVIII", In: II Simpósio Luso-Brasileiro de Cartografia Histórica, Lisboa, 2007, p. 6-7; Tiago Kramer de Oliveira, "Entre dois impérios: as conquistas portuguesas e ruralidade no centro da América do Sul (1734-1750)", In: Leny C. Anzai; Maria Cristina Bohn Martins (orgs.), Histórias coloniais em áreas de fronteiras: índios, jesuítas e colonos, São Leopoldo, Oikos/ Unisinos; Cuiabá, Ed. UFMT, 2008, p. 17-49.

${ }^{44}$ Studying the manifestations of interest for the polar regions and, more specifically, the political issue involving the appropriation of Antarctica, João Frank da Costa recalls that "as a consequence of the discovery of the Western Indias by Cristopher Columbus, Catholic kings, who dismantled the monopoly of the new lands given to Portugal through several papal bulls, worked hard to obtain jurisdictional protection from Alexander VI (bulls Inter Caetera and Eximiae Devotionis). Finally, the second bull Inter Caetera, from May 4, 1493 (which seems to have been issued in June) conceived the Catholic kings, his heirs and successors the islands and land, already discovered or not, to the West of a line going from the North Pole to the South Pole, one hundred leagues away from the Azores islands or Cape Verde. It is also known that the line delimiting the domains of Spain and Portugal was transferred 370 leagues to the west of the Cape Verde islands, by the Treaty of Tordesillas, on June 7, 1494. The clauses of this instrument were confirmed by the bull Ea quae probono pacis, from January 24, 1506, by the Pope Julius II. Despite the violations committed by Spain in the East and by Portugal in the West, such dispositions became theoretically in force between both potencies, until the treaty of Madrid, in 1750". João Frank da Costa, "Antártida: o problema político", Revista Brasileira de Política Internacional, n. 119-12O, Rio de Janeiro, 1987, p. 52-53.
} 
the planet. If the cartographers of the $16^{\text {th }}$ century delimited the imaginary line of the Treaty between $42^{\circ} 30^{\prime}$ e $49^{\circ} 46^{\prime}$ to the West of Greenwich, and agreed to the hypothesis of Frank da Costa that the league adopted in Tordesillas was that of Fernandez de Enciso and Francisco Falero ${ }^{45}$ as 162/3 leagues per degree (and not 15, as considered by Columbus and Américo Vespúcio, nor 17 1/2, as imagined by Pedro Nunes and Pedro Mártir, not even 18, according to Duarte Pacheco Pereira), the line would pass through $48^{\circ} 35^{\prime} 25^{\prime \prime}$ to the West, in the occident, and $13^{\circ} 24^{\prime} 35^{\prime \prime}$ to the East, in the orient. That is, the boundary in the Western side, which is the one we are analyzing, would be very close to Vila Boa de Goiás, whose latitude and longitude were known by Portuguese geographers in 1750 with great accuracy. ${ }^{46}$

Now we know that the exact position of Vila Boa de Goiás is defined by the geographic coordinates $15^{\circ} 56^{\prime} 04^{\prime \prime}$, South latitude, and $50^{\circ} 08^{\prime} 25^{\prime \prime}$, West latitude. In that case, if we consider the coordinates of the meridian defined by the Treaty of Tordesillas, as mentioned earlier, we know that Vila Boa encroached into the Spanish territory by exactly, $1^{\circ} 33^{\prime} 00^{\prime \prime}$ (one degree and thirty-three minutes). That is, about 41 leagues or 246 kilometers. If Portuguese geographers from 1740 had known the longitude of Vila Boa with an error of only $1^{\circ}$ (one degree), we can conclude that the King of Portugal knew where he was standing, and that is why he invested too much in the frontier, aiming to ensure the possession of a larger territory and its natural riches, a part of which really belonged to Spain.

In this context, the definitive increase of Portuguese conquests in America would only be consolidated after the negotiations made by virtue of the Treaty of Madrid. It was necessary in that moment to know the territory precisely and its representation by means of maps and geographic documents. As pointed out by Clemente Ferreira, "they synthetized what was known and understood, supposed or even ignored about a specific space or territory". ${ }^{47}$

The superiority of the Portuguese in comparison with the lack of maps elaborated in Spain during the period prior to the Treaty of Madrid led to a favorable negotiation concerning Portugal's intentions. On one hand, a prolonged period of negligence from the Spanish with respect to the systematic follow-up of the longitudes gave Portugal major autonomy to move around the frontier. On the other hand, the lack of geographic information, especially in the region

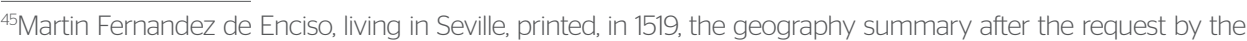
emperor Charles V. To this treaty, destined to navigators and salesmen, he adds everything that was known at the time about the theory and practice of the profession. Francisco Falero was Portuguese and brother of Rui Falero. Both of them arrived in Spain with Magellan. About them, see Douflot de Mofras, Recherche sur le progrès de I'astronomie et des sciences nautiques en Espagne. Extraites des ouvrages espagnols de Don Martin Fernandez de Navarrete, Paris, Imprimerie Royale, 1839.

${ }^{46}$ Referring to the cartographic mistakes in the maps used for the negotiations that led to the Treaty of Madrid, Mario Clemente Ferreira recalls that Alexandre de Gusmão knew the meridian line of the Treaty of Tordesillas with much approximation, as well as the latitude and longitude of Vila Boa de Goiás, calculated with an approximate error of only $1^{\circ}$ (one degree) by the mission of the mathematician priests. Mário Clemente Ferreira, "O Mapa das Cortes e o Tratado de Madrid", Varia Historia, vol. 23, n. 37, Belo Horizonte, 2007, p. 65. ${ }^{47}$ Mário Clemente Ferreira, "O Mapa das Cortes e o Tratado de Madrid", Varia Historia, vol. 23, n. 37, Belo Horizonte, 2007, p. 52.
} 


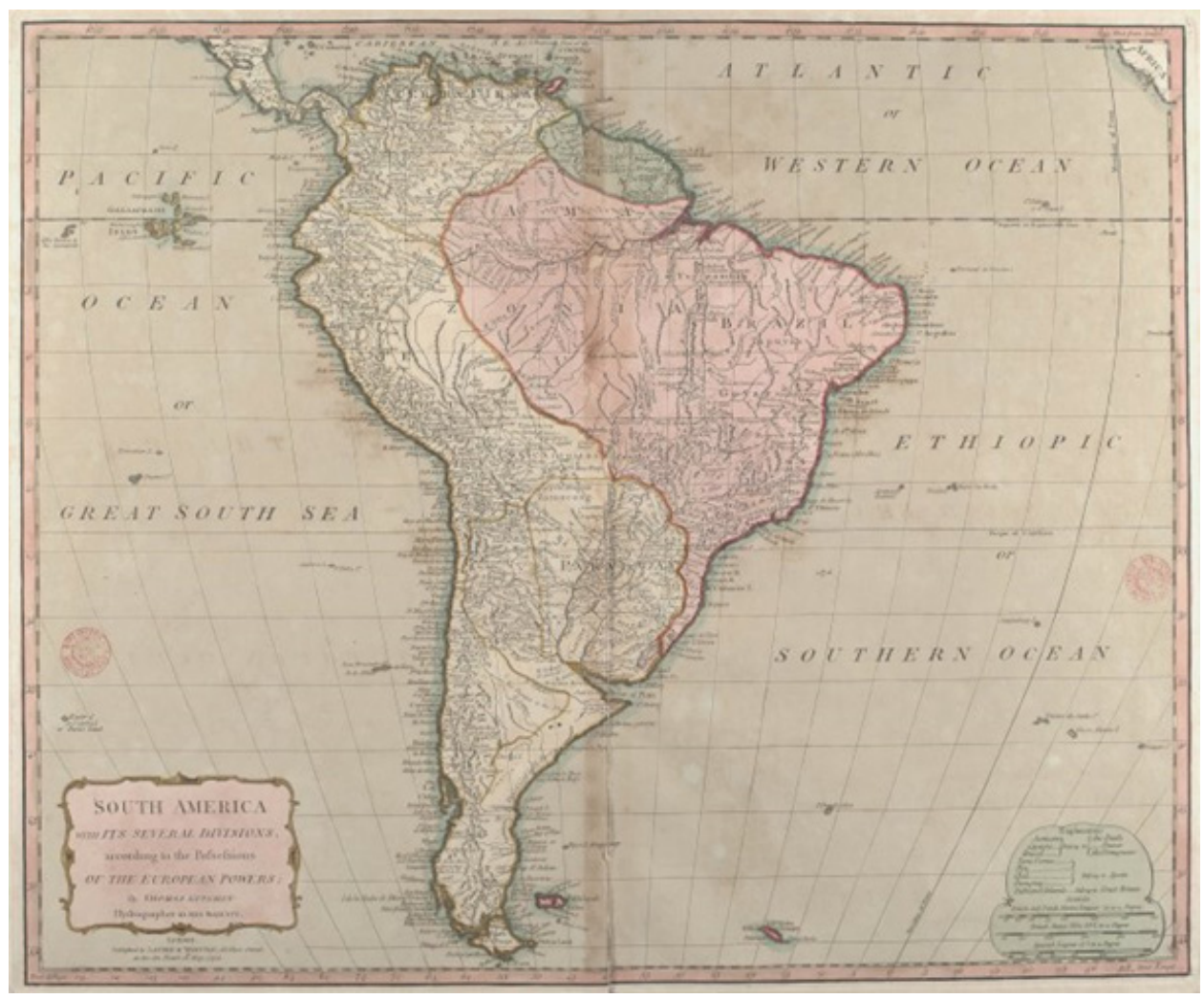

Map 2. Western boundary of Portuguese America over Spanish domain. ${ }^{\text {b }}$

of Chiquitos, disabled the Spanish dealers, since they did not know up to which point the Portuguese were inside Mato Grosso. ${ }^{48}$

The Portuguese Crown came out with a text, "A project of the Treaty of Boundaries", which was sent by Lisbon to the Spanish dealers in November 1747. The text announced the preparation of a complementary geographical map, 'the Map of Courts, ${ }^{49}$ and by virtue of it the diplomatic agreement of 1750 would be established. ${ }^{50}$ To produce this map, it was essential to systematize the information obtained by the incursions made by dwellers both from Mato Grosso and Goiás. This information was used to compose a geographical map prior to the establishment of the Map of Courts, which worked as a guide: Hence the map was produced in 1746 under the auspices of the Governor of

\footnotetext{
${ }^{48} / \mathrm{dem}$, Ibidem

${ }^{49}$ Letter from M. A. de Azevedo Coutinho to Tomás da Silva Teles; Lisboa, 14 de dezembro de 1748, apud Jaime Cortesão, Alexandre de Gusmão e o Tratado de Madrid, parte IV, tomo I, documento 60, p. 252.

${ }^{50}$ Jaime Cortesão, História do Brasil nos Velhos Mapas, vol. 2, Rio de Janeiro, Ministério das Relações Exteriores Instituto Rio Branco, 1971, p. 251. Sobre o Mapa das Cortes, ver Jorge Pimentel Cintra, "O mapa das cortes: perspectivas cartográficas", Anais do Museu Paulista, vol. 17, n. 2, São Paulo, jul-dez. 2007, p. 39-61.

'thomas Kitchin (1718-1784). South America with its several divisions, according to the possessions of the european powers [Cartographic Material]/by Thomas Kitchin, Hydrographer to His Magesty. The map presents the following information related to the date: "as the Act Directs 12th May, 1794". CDU 918(084.3). 912"17"(084.3). Cartography of Brasil in the Biblioteca Nacional collections (1700-1822), Biblioteca Nacional, Lisboa.
} 
Rio de Janeiro, Gomes Freire de Andrade, probably after getting a request from Alexandre de Gusmão.

The map of 1746 focused on the territories that were close to the Spanish domain, and presented therein especially the group of mining regions. It specifically showed the Route of Monsoons, from São Paulo to Cuiabá, and the alternative land route connecting the extreme West to the mines of Goiás. It also represented the contacts established by the Portuguese during the 1730s and the 1740s with the Spanish missions of Moxos and Chiquitos, as well as the exploratory trips made inside Goiás. ${ }^{51}$ of the dweller Amaro Leite Moreira.

Therefore, while working on the definition of the frontier between both Empires, in the internal spaces of Portuguese America a vast knowledge based on local information was built. This provided new definitions as to the boundaries of regional micro frontiers. It is worth to mention that there is a lack of definition about the geographical lines delimiting the territory associated with the mines of Goiás. This territory always attracted the attention of Colonial authorities, as it was the target of serious disputes involving Representatives of the Crown, local authorities and dealers, and even members of the Church who were working in Portuguese America.

That is why, as soon as Marcos de Noronha took over the Government of the Captaincy of Goiás, he was asked by Lisbon to analyze and define the matters connected with the boundaries of the Captaincy. He was asked specially to define the frontiers with the Captaincy of Mato Grosso. Therefore, in January, 1750, in a letter to the King of Portugal, the Governor presented a very precise sketch depicting the boundaries of the Captaincy. ${ }^{52}$

This effort made by Marcos de Noronha resulted in the production of a map in 1751, made by Francisco Tosi Colombina. ${ }^{53}$ This was used, in 1753, to present the delimitation of the boundaries of the Captaincy of Goiás to the King. It was then used to integrate the "Project of Boundaries", created in Lisbon. In this geographical document, the territory of Goiás appeared for the first time with its peculiarities constituting the "Birth Certificate" of Goiás, according to

\footnotetext{
${ }^{51}$ Mário Clemente Ferreira, "O Mapa das Cortes e o Tratado de Madrid", Varia Historia, vol. 23, n. 37, Belo Horizonte, 2007, p. 60-61.

${ }^{52} \mathrm{AHU} / \mathrm{GO} /$ Letter of the governor and general captain of Goiás, Marcos de Noronha, to the king John V, in response to the provision about how to proceed as to the geographical boundaries of the captaincy of Goiás; Vila Boa de Goiás, 12 de janeiro de 1750 [Cx. 6, D. 429].

${ }^{53}$ According to the secretary of government, Ângelo Santos Cardoso, Tosi Colombina arrived in Goiás in 1749, integrating the group of the new internal affairs Agostinho Luiz Vieira, as a cosmographer (as the old cartographers were known), in the same period of the arrival of the first governor, Marcos de Noronha. Cf. AHU/GO/Document of the secretary of government of Goiás, Ângelo dos Santos Cardoso, to the secretary of State of the Marine and overseas, Diogo de Mendonça Corte Real, about the discovery of the mines in Goiás; its population; the character of the first miners and liberal professionals; civil and ecclesiastic governments and existing issues; Vila Boa de Goiás, April 15, 1755 [Cx. 12, D. 740]. According to Teixeira Neto, "his cartographic work, of which he was proud for being one of the most accurate ones in Brazil, was actually an expeditious and practical cartography, since it was only based on information from bandeirantes and explorers of the time". However, not even that loses its importance in the context of maps back. Cf. Antônio Teixeira Neto, "Os caminhos de ontem e de hoje em direção a Goiás-Tocantins", Boletim Goiano de Geografia, vol. 21, n. 1, Goiânia, 2001, p. 58.
} 
Teixeira Neto. He has presented this in an analogy of what the letter from Pero Vaz de Caminha represented to Brazil. ${ }^{54}$

But the primacy of Tosi Colombina could not be sustained since an unknown geographer had previously prepared another map, even before the creation of this "Birth Certificate" of Goiás. This not only overshadowed the precedence of Colombina, as suggested by Teixeira Neto, but also served as a reference and starting point for Tosi Colombina's work. ${ }^{55}$

\section{The superiority of the Portuguese in comparison with the lack of maps elaborated in Spain led to a favorable negotiation concerning Portugal's intentions}

Indeed, requested by the Secretary of the Government of mines of Goiás, Ângelo dos Santos Cardoso, another geographical map was produced and sent to Alexandre de Gusmão in May, 1750. In a report addressed to Sebastião José de Carvalho e Mello, Secretary of State from 1750 on and future Marquis of Pombal, Santos Cardoso clearly refers to a map prior to the one by Tosi Colombina, which he textually states to have sent, personally, to Lisbon:

In the same reality in which I arrived to this village, accompanied by Mr. General Gomes Freire de Andrada", says the secretary, "there was also an Italian man named Francisco Tosi Columbina, in the escort of the new superintendent Agostinho Luiz Vieira, who was coming to this district; after almost one year, Columbina went across the district with the same superintendent; and was requested by Mr. Conde dos Arcos, general of this captaincy, to observe the heights of the villages, and situations of the same district; due to curiosity, it was discovered that he was fond of Geography; the aforementioned Columbina asked me for a copy of the map, which I had on my hands, and had sent the original to the Court to Alexandre de Gusmão, and based on that he formed a new one, with few differences, except for some

\footnotetext{
54"Mapa da Capitania de Goyaz e regiões circunvizinhas que mostra as comunicações entre as bacias do Prata e do Amazonas", de Francisco Tosi Colombina, Vila Boa de Goiás, 6 de abril de 1751. The map is a manuscript watercolor map, stored in the board of the Geographic Service, in Rio de Janeiro. There is another copy in the Public Archive of Minas Gerais, as well as current copies stored in the National Library of Rio de Janeiro.

${ }^{55} \mathrm{AHU} / \mathrm{GO} /$ Document of the secretary of government of Goiás, Ângelo dos Santos Cardoso, to the secretary oof state of the Marine and overseas, Diogo de Mendonça Corte Real, about the discovery of the mines in Goiás; its population; the character of the first miners and liberal professionals; civil and ecclesiastic governments and existing issues; Vila Boa de Goiás, 15 de abril de 1755 [Cx. 12, D. 740].
} 
changes in heights and degrees of the villages, and some rivers or new locations $[\ldots]^{56}$

Based on these indications and on the suggestions by Paulo Bertran, the preeminence of the maps elaborated by Francisco Tosi Colombina becomes questionable. ${ }^{57}$

\section{Conclusion}

Finally, based on this set of information, the King Joseph I signed the provision in September, 1751: "about measuring the Colony and boundaries of America", addressed to the Governor of Rio de Janeiro, Gomes Freire de Andrade. At the same time, he informed the trustee of the Royal Treasury of the Captaincy of Goiás that he had established a Treaty on boundaries in America with El Rei de Castela.

[...] to stop the disputes that were occurring between my vassals and those of that Crown, or those that could occur in the intelligences of meridian and imaginary lines [...] by reducing the boundaries of both monarchies and those appearing in the aforementioned treaty with the names of rivers, mounts and countries. ${ }^{58}$

On the basis of the above, the Royal Treasury in Goiás was directly contacted by the King of Portugal on the subject of essential relevance for the Portuguese Monarchy: about financing, with the gold produced in the mines of Goiás, expenses with geographers and officials responsible for delimiting and dividing the "land of the colony". However, the response of the trustee, Anastácio de Nóbrega, was harsh and precise:

However I should always represent Your Majesty, says the intendant to the king of Portugal, that this trustee is taxed with so many costs, and its expenses are much higher than its income, with

\footnotetext{
${ }^{56} \mathrm{AHU} / \mathrm{GO} /$ Document of the secretary of government of Goiás, Ângelo dos Santos Cardoso, to the secretary oof state of the Marine and overseas, Diogo de Mendonça Corte Real, about the discovery of the mines in Goiás; its population; the character of the first miners and liberal professionals; civil and ecclesiastic governments and existing issues; Vila Boa de Goiás, 15 de abril de 1755 [Cx. 12, D. 740].

${ }^{57}$ See in Wilson Carlos Jardim Vieira Júnior; Andrey Rosenthal Schlee; Lenora de Castro Barbo, "Tosi Colombina, autor do primeiro mapa da Capitania de Goiás?", História e-história, Unicamp, 2010. Disponível em: <http:// www.historiaehistoria.com.br>. Acesso em: 25 de maio de 2010. Conferir, também, em Paulo Bertran, História da terra e do homem no Planalto Central: eco-história do Distrito Federal, do indígena ao colonizador, Brasília, Verano, 2000.

${ }^{58} \mathrm{AHU} / \mathrm{GO} / \mathrm{Letter}$ of the intendant and provider of the Royal Treasury of Goiás, Anastácio da Nóbrega, to king Joseph I, about carrying out the provision to help geographers and officials of the division of the land in the colonies, with the amount of Money established by the governor and general captain of Rio de Janeiro, Gomes Freire de Andrade, and because the trustee of Goiás was overburdened; Vila Boa de Goiás, May 30, 1753 [Cx. 8, D. 575].
} 
costs essentially necessary, so with great difficulty it will be possible to cover any possible new expenses. ${ }^{59}$

As observed, Anastácio da Nóbrega, in 1753, showed signs of dissatisfaction with the huge sums of gold used for the maintenance and protection of the frontier at the extreme West of Brazil. For a long time, the gold of Goiás would be used for supporting the Colonial project and the ambitions of the King of Portugal in the central region of South America.

The deals defined by the Treaty of Madrid did not last long as it was opposed vehemently by powerful enemies: The Spanish Jesuits who had been banned from the missions and salesmen who could not practice smuggling of the gold in Rio de la Plata (River Plate). These protests found an unexpected support from Portugal, on behalf of the Marquis of Pombal. Hence a new deal - the El Pardo - was established on February 12, 1761, which annulled the Treaty of Madrid. But the geographic and jurisdictional bases which Alexandre de Gusmão fought so hard fo, ended up in 1750. In 1777, those annulled principles came back, in the Treaty of Santo Ildefonso. ${ }^{60}$ The strategic dimension of the final result cannot be ignored. In the opinion of the geographer Teixeira Neto,

All of this resulted in one of the most well-elaborated geopolitical projects throughout the history of Brazil: one involving diplomatic, technical and scientific preparation of the Treaty of Madrid - signed in 1750 between Portugal and Spain -, which gave form, solidity and legitimacy to the frontiers and boundaries of Brazil and to the occupation, population and urbanization of all of the forms of the Brazilian Center-West and Amazon. ${ }^{61}$

With this line of thinking, we see the region of mines of Goiás was a central geopolitical axis in the colonial project conceived by Lisbon for the Portuguese America. The Portuguese had established an administrative, jurisdictional and religious apparatus, little by little. The control and the power of the Crown in the region, and the preeminence of the Monarch's interests appear to be more solid due to the stimulation provided for the founding of villages and cities. Therefore, in

\footnotetext{
${ }^{59} \mathrm{AHU} / \mathrm{GO} / \mathrm{Letter}$ of the intendant and provider of the Royal Treasury of Goiás, Anastácio da Nóbrega, to king Joseph I, about carrying out the provision to help geographers and officials of the division of the land in the colonies, with the amount of Money established by the governor and general captain of Rio de Janeiro, Gomes Freire de Andrade, and because the trustee of Goiás was overburdened.; Vila Boa de Goiás, May 30, 1753 [Cx. 8, D. 575]

${ }^{60}$ The Treaty of Santo Ildefonso was signed on October 1st, 1777, in the city of San IIdefonso, in the Spanish Province of Segovia, with the objective of finishing the dispute between Portugal and Spain for the colonial possession of the South-American colony of Sacramento, since this situation was prolonged since the Peace of Utrecht and the war from 1735-1737. The treaty was intermediated by England and France, who had international political interests in the pacification of the two Iberian countries. After the treaty was signed, the queen of Portugal, Maria I, and the king of Spain, Charles III, practically revalidated the treaty of Madrid (1750) and conceived juridictional base to a situation: the Spanish maintained the colony and the region of Sete Povos das Missões, which then composed most of the state of Rio Grande do Sul and Uruguai; in exchange, they recognized the sovereignty of the Portuguese on the left margin of the River Plate, and donated some frontier land to make up for the advantages obtained in the south, and gave back the island of Santa Catarina.

${ }^{61}$ Antônio Teixeira Neto, "Cartografia, território e poder: dimensão técnica e política na utilização de mapas", Boletim Goiano de Geografia, vol. 26, n. 2, Goiânia, 2006, p. 56.
} 
the mid $18^{\text {th }}$ century, the strategic presence of the King of Portugal in the Western frontier of Portuguese America was consolidated by the establishment of the material bases of the Portuguese dominion in relation to the Spanish dominion.

In this scenario, built in the heart of America, the Captaincy of Goiás and its Capital, Vila Boa, constituted an advanced position in the West. It was located beyond the boundaries of the line defined by the Treaty of Tordesillas, which met the interests of the Portuguese Government in two essential dimensions: On the one hand, as the center of a fiscal and administrative structure that was able to provide gold extraction. On the other hand, as a strategic support point - offering material, human and financial support - which helped its anchoring and ensuring an organized base. This had also reduced the conflicts at this last Colonial border. 